\title{
Genetic identification of Javan hawk-eagle (Nisaetus bartelsi) from Indonesia using mitochondrial COI gene
}

\author{
Suhadi*, Dwi Listyorini, Riri Wiyanti Retnaningtyas, Fima Rizki Eka Putri, Dina Ayu \\ Valentiningrum
}

Department of Biology Faculty of Mathematics and Natural Sciences State University of Malang, Indonesia

Received 28th December 2018 / Accepted 21st March 2019

\begin{abstract}
Nisaetus bartelsi is a native hawk from Java which its genetic information is not commonly understood yet. As a part of the conservation effort to maintain genetic diversity of this endangered species, this research aimed to obtain COI gene sequences from five individuals of N. bartelsi to confirm its position in the phylogenetic tree. DNA isolation from $5 \mathrm{~N}$. bartelsi blood sample was performed and its COI gene sequence was amplified, sequenced, and used to reconstruct phylogenetic tree using MEGA 6 with several other members of Nisaetus, Aquila, and Saggitaridae family. Furthermore, the intraspecific distance between $5 \mathrm{~N}$. bartelsi samples and interspecific distance with other species were calculated using MEGA6. The result suggested that all five individuals belonged to the species Javan hawk-eagle (N. bartelsi) and were closely related to the Blyth's hawk-eagle (Nisaetus alboniger). The DNA barcoding of the Javan hawk-eagle conducted in this study is a stepping stone to conservation efforts for the Javan hawk-eagle.
\end{abstract}

Keywords: conservation, cytochrome-c oxidase subunit I, DNA barcoding, Javan hawk-eagle

\section{INTRODUCTION}

The Indonesian archipelago is renowned for its enormous species endemicity due to its geographical condition. One of the endemic species of Indonesia is the Javan hawk-eagle (Nisaetus bartelsi) (Nijman \& Sözer, 1998), a diurnal bird of prey living solely in the tropical rainforest of Java (Van Balen et al., 2000). This species mostly inhabits primary rainforest (Van Balen et al., 2001) and is also frequently seen in secondary or even production forests in Java (Syartinilia \& Tsuyuki, 2008) ranging from sea level to high mountains, with the most frequent appearance found at 500-1000 m. Furthermore, the estimated average home range of one pair is approximately 400 ha (Gjershaug et al., 2004). The preferred diet of Javan hawk-eagles varies from small mammals to birds and reptiles (Prawiradilaga, 2006).

Javan hawk-eagles' resemblance to the mythical creature Garuda, which is also the national emblem of Indonesia, has made this species a prominent focus for avian conservation in Java (Van Balen et al., 2000). Furthermore, since the declaration of this species as a National Rare/Precious Animal of Indonesia in 1992 (Widyastuti, 1993), public awareness about the need to preserve their habitat, along with natural resources that support it, has increased. However, this rising awareness has also increased its demand in illegal wildlife trade since in Javanese culture, bird keeping, especially the keeping of expensive and rare birds, is a way to exhibit one's social status (Nijman, 2009).

The population of this species is decreasing despite the legal status of the Javan hawk-eagle and the ongoing conservation efforts (IUCN, 2016; BirdLife International, 2016). The estimated

* Author for correspondence: Suhadi, Jl. Semarang No. 5, Malang, East Java 65145, Indonesia. Email - Suhadi@um.ac.id 
population of Javan hawk-eagles throughout the island of Java is around 600-900 individuals, which roughly equals 300-500 mature individuals (IUCN, 2016). The reason for this decrease, besides illegal wildlife trade, is deforestation (Sozer et al., 1998; Collar et al., 2001; Nijman, 2009), which eventually leads to habitat fragmentation (Van Balen et al., 2000). As a result, Javan hawk-eagle populations throughout Java are severely fragmented and, most likely, isolated from each other (Van Balen et al., 20001. Meanwhile, isolated populations are vulnerable to inbreeding depression, which affects birth weight, survival, reproduction and disease resistance due to the loss of genetic diversity within the population; populations with these conditions are prone to extinction (Keller \& Waller,2002).

In response to the race against extinction caused both by human disturbance and inbreeding depression, conservation efforts at the molecular level are necessary in order to save any records of the species, including their genetic data, and to maintain the phylogenetic diversity of the Javan hawk-eagle (Frankham, 2003). Taxonomic or phylogenetic distinctiveness is one determining factor in establishing conservation priorities for threatened species, like the Javan hawk-eagle (IUCN, 1980).

In the previous phylogenetic study based on mtDNA sequences $C y t-b$ and non-coding control region, Nisaetu bartelsi is sister species to Nisaetus alboniger forming a distinct clade apart from Nisaetus kelaarti and Nisaetus nipalensis; both Nisaetus bartelsi and Nisaetus alboniger belong to the Asian hawk-eagle monophyletic cluster apart from their relatives Spizaetus genus in South America (Haring et al., 2007). Due to the short cyt$\mathrm{b}$ sequence, the phylogenetic tree in the previous study resulted in low bootstrap values in the phylogenetic tree especially in the deeper nodes, indicating that further genetic analysis using higher resolution genetic markers is necessary (Haring et al., 2007). Further study based on mitochondrial genes $C y t-b$ and 5 nuclear loci also support that Nisaetus bartelsi is sister species to Nisaetus alboniger and both taxa form a separate clade from Nisaetus nipalensis (Lerner et al., 2017). Nevertheless, to clarify the phylogenetic distinctiveness of Javan hawk-eagles, a database of the COI gene is needed.

The cytochrome-c oxidase subunit I (COI) gene is a short sequence of mitochondrial DNA (648-780 bp) that serves as a standardized molecular marker, or commonly known as a DNA barcode, for biological identification with precision up to the species level due to its low variability $(1-2 \%)$ and low rate of amino acid changes (Hebert et al., 2003; Hebert et al., 2004; Hajibabaei et al., 2007). DNA barcodes can provide a clarification of the genetic distinctiveness of a species by confirming the species name of the taxa based on its unique COI gene sequence (Hajibabaei et al., 2007). To date, however, there is still a lack of reports in GenBank on the genetic data, especially the COI gene, of Javan hawk-eagles living in the primary forests on the island of Java.

A thorough phylogenetic analysis is needed to trace the genetic diversity of this species and to address the lack of genetic data for the Javan hawk-eagle. This is needed to inform conservation programs that aim to preserve the genetic diversity of distinguishable taxonomic units (Lerner \& Mindle, 2005). This should be done since concerns about the evolutionary information loss of a species are one of the basic motivations of nature conservation itself (Winter et al., 2012). The COI gene sequence of the Javan hawk-eagle can provide deep insight into the phylogenetic diversity of this species, since it is used as a base to reconstruct a phylogenetic tree and is highly useful in estimating the relationship amongst species, as well as its evolution (Hajibabaei et al., 2007; Winter et al., 2012). Furthermore, the phylogenetic diversity that is defined with DNA barcode sequence data may serve as the most important measure for comparing genetic diversity and establishing a protected habitat across the landscape of Javan rainforests. Additionally, as the DNA barcode database library contains genetic data of species from across the globe, a comparative measure of phylogenetic diversity can serve as a standard metric for conservation assessment (Kress et al., 2015).

The Javan hawk-eagle belongs to the family Accipitridae, along with the other members of genus Nisaetus, such as $N$. nipalensis, $N$. alboniger, $N$. cirrbatus, $N$. kelaarti, and N. floris. By comparing the COI gene sequence of $N$. bartelsi with COI genes from the rest of the genera Nisaetus and Spizaetus, we can determine the position of $N$. 
bartelsi in the phylogenetic tree. Accordingly, this research aims to obtain the COI gene sequences from 5 individuals of Javan hawk eagle (Nisaetus bartelsi) to confirm this species position in the phylogenetic tree.

\section{MATERIALS AND METHODS}

Collection of samples. This research was conducted from December 2016 to February 2017 in the Genetic Regulation Laboratory and Biotechnology Division of Central Laboratory of Mineral and Advanced Material, State University of Malang. Javan hawk eagle's individual which used in this study were from Eco Green Park in Batu City (two individuals; encoded as FM01 and FW01), Cikananga Wildlife Centre in Sukabumi District (two individuals, encoded as RR21 and RR24), and Animal Sanctuary Trust Indonesia (ASTI) in Bogor City (an individual; encoded as RR04). The morphological data was based on morphometry and some supporting profiles provided by Cikananga Wildlife Centre, ASTI and Eco Green Park.

\section{Isolation of $\mathrm{DNA}$ and amplification of $\mathrm{COI}$}

gene. Materials of DNA which used in this study were blood samples taken from pectoralis subclavian veins of each Javan hawk-eagle individual, which were stored in $1000 \mu$ l of absolute alcohol. Each blood sample was collected by veterinarians in Eco Green Park, Cikananga Wildlife Center, and ASTI respectively. Samples were sent to the laboratory mentioned above for DNA isolation and COI gene amplification.

Isolation of DNA was performed using DNeasy Blood and Animal Tissue Kit (Qiagen, Cat. No. 69504). Amplification of COI gene was performed using COI primers: (1) forward 5'TTC TCC AAC CAC AAA GAC AT'T GGC AC3' and (2) reverse 5' ACT ACA TGT GAG ATG ATT CCG AAT-3' (Zein \& Prawiradilaga, 2013). COI gene was amplified through polymerase chain reaction (PCR) which consisted of an initial denaturation of $95^{\circ} \mathrm{C}$ for 5 minutes, followed by five cycles of $94^{\circ} \mathrm{C}$ denaturation for 1.5 minutes, $54^{\circ} \mathrm{C}$ annealing for 1.5 minutes and $72^{\circ} \mathrm{C}$ extension for 1.5 minutes. Following this, 30 cycles of $94^{\circ} \mathrm{C}$ denaturation for 1.5 minutes, $57^{\circ} \mathrm{C}$ annealing for 1.5 minutes, $72^{\circ} \mathrm{C}$ extension for 1.5 minutes, then the final extension at $72^{\circ} \mathrm{C}$ for 5 minutes (Zein \& Prawiradilaga, 2013). Amplification results were then visualized by performing electrophoresis in 1\% agarose gel. After the targeted band of approximately $700 \mathrm{bp}$ was visible, the samples were then sent to First Base Laboratories Malaysia for sequencing.

Analysis of the sequencing result. Sequencing results (in the form of chromatograms of forward and reverse sequence for each sample) were read using FinchTV software (CDigital World Biology LLC), trimmed using MEGA6 based on the read peaks, and combined using DNA Baser to create a consensus sequence (Heracle BioSoft SRL). Multiple alignments were performed using ClustalX2 among forward and reverse sequence for each sample and among encoded samples to produce consensus sequence. Multiple alignment analysis was also used to find the similarity index of consensus sequence from samples against $N$. alboniger as the same genus from BOLDsystem database (using BOLD system alignment browser) and $S$. alboginer (accession code: AP008239.1) and S. nipalensis (accession code: AP008238.1) as one family from GeneBank (using Basic Local Alignment Search Tool or BLAST analysis).

Pairwise genetic distance and similarity index were conducted among five encoded samples, $S$. alboniger as the closest relative and Sagittarius serpentarius as outgroup species. Intraspecific and interspecific genetic distance in comparison with the members of the Nisaetus genus was conducted using MEGA 6 (Tamura et al., 2013).

The phylogenetic tree analysis was conducted using MEGA 6 with the neigh-borjoining (NJ) (Nei \& Saitou, 1987) method according to Kimura 2-parameter distance with five encoded samples and some species provided in GeneBank of National Center for Biotechnology Information (NCBI) for comparison. The species that included for the reference species were in the Nisaetus genus (N. Alboniger accession AP008239.1, N. cirrbatus ROMC331-07, N. tyrranus JQ176245.1, N. melanoleucus JQ176244.1, N. philppensis HM639912.1, N. nipalensis AP008238.1, AB843766.1, AB843173.1, AB843767.1, AB843172.1, AB843171.1, AB843170.1), Aquila 
genus (Aquila chrysaetos GU571264.1 and GU571738.1), and outgroup from Saggitaridae family (Sagittarius serpentarius U83776.1).

\section{RESULTS AND DISCUSSION}

The similarity of encoded samples' species and another. The morphological study conducted on the sample FW01 and FM01 showed that the individuals were 2-3 years old Javan hawk-eagles (Nisaetus bartelsi) or were categorized as juveniles along with the sample RR04, RR21, and RR24. The COI gene amplification and electrophoresis results suggested that the targeted gene of approximately 700 bp was obtained. The sequencing results of the five samples, with the code names FM01, FW01, RR04, RR21, and RR24, showed 744, 742, 734, 724, and 741 base pairs, respectively (Figure 1). The identification results from BOLDSystem indicated that each sample was closely related to N. alboniger, with a similarity above $98 \%$ (Table 1) as there was no similarity at the species level to any sample available in the system due to the lack of genetic information on this species, especially for COI gene. The tree-based identification performed in BOLDSystem also revealed the same results. FM01, FW01, RR04, RR21, and RR24 each formed a sister species clade with $N$. alboniger. However, further analysis using pairwise genetic distance amongst the five samples and $N$. alboniger were necessary to gain further insight into the similarity between the two closely related taxa. According to Table 2, BLAST results of the Javan hawk-eagle COI gene sequence with the GenBank database suggests that the COI gene sequence with the highest similarity was Spizaetus alboniger, with a query coverage of $99 \%$ and a similarity of $98 \%$.

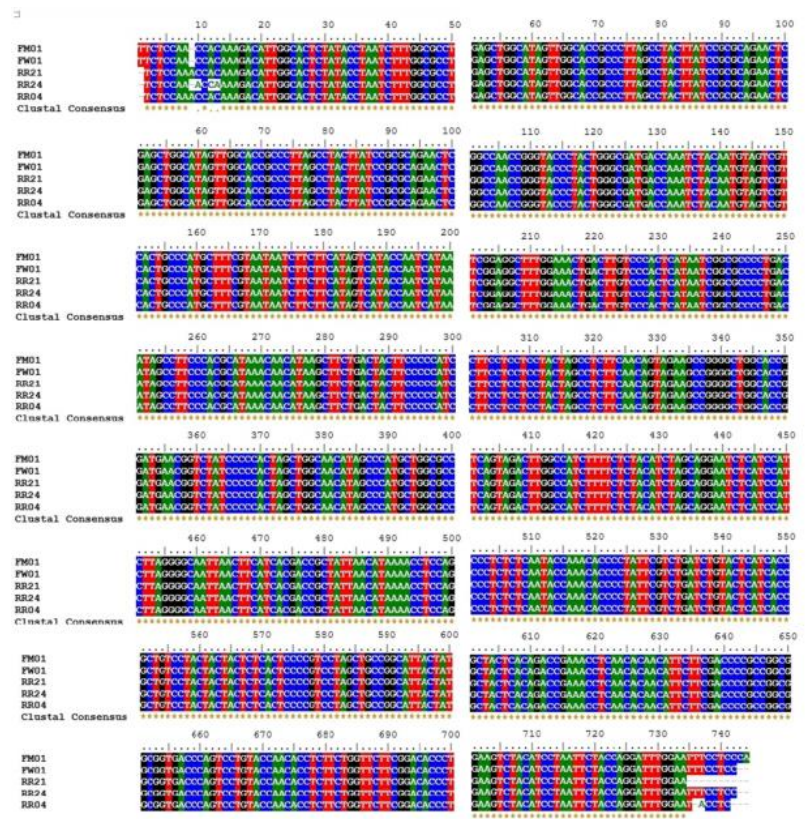

Figure 1. The consensus of forward and reverse sequence of the COI gene of samples FM01, FW01, RR21, RR24, and RR04, with lengths of $744 \mathrm{bp}, 742 \mathrm{bp}, 734 \mathrm{bp}, 742 \mathrm{bp}$, and $741 \mathrm{bp}$ respectively.

Table 1. The similarity of javan hawk-eagle from samples against $N$. alboniger.

\begin{tabular}{ccc}
\hline No & Sample code & Similarity (\%) \\
\hline 1 & FW01 & 98.35 \\
2 & FM01 & 98.35 \\
3 & RR04 & 98.30 \\
4 & RR21 & 98.35 \\
5 & RR24 & 98.51 \\
\hline
\end{tabular}

Table 2. The similarity of N. bartelsi from samples against Spizaetus genus.

\begin{tabular}{ccccc}
\hline No & Species & Accession code & Query cover (\%) & Similarity (\%) \\
\hline 1 & Spizaetus alboniger & AP008239.1 & 99 & 98 \\
2 & Spizaetus nipalensis & AP008236.1 & 98 & 97 \\
\hline
\end{tabular}

The genetic distance of Javan hawk-eagle and other species. According to the pairwise genetic distance of the five samples, with $S$. alboniger AP008239.1 as the closest relative and Sagittarius serpentarius U83776.1 as an outgroup, samples FM01, FW01, RR04, RR21, and RR24 had a pairwise genetic distance of 0.000 , meaning that all samples had no difference in their COI gene sequences. The genetic distance of 0.000 for each sample thus indicated that all samples belonged to the same species. Furthermore, the pairwise genetic distance of each of the five individuals of 
$N$.bartelsi compared to $N$. alboniger or $S$. alboniger AP008239.1 supported the previous result by showing a genetic distance of 0.021 ; in other words, the similarity of the said taxa was $97.9 \%$ (Table 3), meaning that the five samples and $S$. alboniger AP008239.1 were sister species since genetically distinct but closely related species show low divergences, ranging from $0.6-2.0 \%$, while divergence values between species are ordinarily greater than 3\% (0.03) (Hebert et al., 2003).

The confirmed status of the five samples as Javan hawk-eagles (N. bartelsi), according to their pairwise genetic distances, became the ground for the grouping in the intraspecific and interspecific genetic distance analysis. According to the intraspecific genetic distance analysis, the Javan hawk-eagle (N. bartelsi) has no genetic variation within the species with a genetic distance of 0.000 (Table 4). This implied that there was no genetic variation within the species group of Nisaetus bartelsi consisting of the five samples; thus, it did not only confirm the species label as Javan HawkEagle (Nisaetus bartelsi) but also the fact that the five individuals COI gene sequences were conserved regardless the habitat fragmentation that isolates the population. However, to confirm this, more data on COI gene sequences of Javan hawk-eagle is needed.

Table 3. Pairwise genetic distance amongst N. bartelsi, S. alboniger (ingroup; accession code: AP008239), and Sagittarius serpentarius (outgroup; accession code: U83776).

\begin{tabular}{llllllll}
\hline & RR24 & FW01 & FM01 & RR21 & RR04 & AP008239 & U83776 \\
\hline RR24 & \multicolumn{2}{c}{0.000} & 0.000 & 0.000 & 0.000 & 0.007 & 0.0027 \\
FW01 & 0.000 & & 0.000 & 0.000 & 0.000 & 0.007 & 0.027 \\
FM01 & 0.000 & 0.000 & & 0.000 & 0.000 & 0.007 & 0.027 \\
RR21 & 0.000 & 0.000 & 0.000 & & 0.000 & 0.007 & 0.027 \\
RR04 & 0.000 & 0.000 & 0.000 & 0.000 & & 0.007 & 0.027 \\
AP008239 & 0.021 & 0.021 & 0.021 & 0.021 & 0.021 & & 0.026 \\
U83776 & 0.217 & 0.217 & 0.217 & 0.217 & 0.217 & 0.209 & \\
\hline
\end{tabular}

Table 4. The intraspecific genetic distance of N. bartelsi against few species from Genebank.

\begin{tabular}{ccc}
\hline Genebank species & Distance & Standard Error \\
\hline S. tyrannus & $\mathrm{n} / \mathrm{c}$ & $\mathrm{n} / \mathrm{c}$ \\
N. bartelsi & 0.000 & 0.000 \\
S. alboniger & $\mathrm{n} / \mathrm{c}$ & $\mathrm{n} / \mathrm{c}$ \\
N. nipalensis & 0.000 & 0.000 \\
Sagittarius serpentarius & $\mathrm{n} / \mathrm{c}$ & $\mathrm{n} / \mathrm{c}$ \\
Aquila chrysaetos & 0.000 & 0.000 \\
S. melanoleucus & $\mathrm{n} / \mathrm{c}$ & $\mathrm{n} / \mathrm{c}$ \\
N. cirbhatus & $\mathrm{n} / \mathrm{c}$ & $\mathrm{n} / \mathrm{c}$ \\
S. philippensis & $\mathrm{n} / \mathrm{c}$ & $\mathrm{n} / \mathrm{c}$ \\
\hline
\end{tabular}

$\mathrm{n} / \mathrm{c}$ : not covered and genetic distance's value was very high

Interspecific genetic distance was analyzed to disclose the relationship amongst the species $N$. bartelsi with the other closely related taxa. The data revealed that Nisaetus alboniger had a genetic distance of 0.013 compared to N. bartelsi, which supports its status as the sister species of the Javan hawk-eagle ( $N$. bartelsi). Moreover, the next closest relative of $N$. bartelsi was Nisaetus nipalensis, with a genetic distance of 0.021 . The furthest relative of $N$. bartelsi, according to the interspecific genetic distance, was $S$. tyrannus, with a genetic distance of 0.111 (Table 5). 
Table 5. Interspecific genetic distance of few genus in Accipitridae family.

\begin{tabular}{|c|c|c|c|c|c|c|c|c|c|}
\hline C & $\begin{array}{c}\text { S. } \\
\text { tyrannus }\end{array}$ & $\begin{array}{c}N . \\
\text { bartelsi }\end{array}$ & $\begin{array}{c}S . \\
\text { alboniger }\end{array}$ & $\begin{array}{c}N . \\
\text { nipalensis }\end{array}$ & $\begin{array}{l}\text { Sagittarius } \\
\text { serpentarius }\end{array}$ & $\begin{array}{l}\text { Aquila } \\
\text { chrysateos }\end{array}$ & $\begin{array}{c}S . \\
\text { melanolencus }\end{array}$ & $\begin{array}{c}\text { N. } \\
\text { cirrbatus }\end{array}$ & $\begin{array}{c}. \\
\text { philippensis }\end{array}$ \\
\hline S. tyrannus & & 0.017 & 0.016 & 0.016 & 0.074 & 0.016 & 0.014 & 0.016 & 0.015 \\
\hline N. bartelsi & 0.111 & & 0.005 & 0.007 & 0.071 & 0.015 & 0.014 & 0.013 & 0.014 \\
\hline S. alboniger & 0.108 & 0.013 & & 0.006 & 0.071 & 0.015 & 0.014 & 0.013 & 0.014 \\
\hline $\begin{array}{c}N . \\
\text { nipalensis }\end{array}$ & 0.103 & 0.021 & 0.021 & & 0.069 & 0.015 & 0.014 & 0.013 & 0.014 \\
\hline $\begin{array}{l}\text { Sagittarius } \\
\text { serpentarius }\end{array}$ & 0.870 & 0.850 & 0.856 & 0.850 & & 0.072 & 0.072 & 0.071 & 0.071 \\
\hline $\begin{array}{l}\text { Aquila } \\
\text { chrysaetos }\end{array}$ & 0.099 & 0.088 & 0.088 & 0.086 & 0.850 & & 0.015 & 0.015 & 0.016 \\
\hline $\begin{array}{c}\text { S. } \\
\text { melanoleucus }\end{array}$ & 0.076 & 0.091 & 0.093 & 0.088 & 0.870 & 0.091 & & 0.014 & 0.014 \\
\hline N. cirrbatus & 0.102 & 0.081 & 0.076 & 0.081 & 0.850 & 0.091 & 0.089 & & 0.009 \\
\hline $\begin{array}{c}S . \\
\text { philippensis }\end{array}$ & 0.094 & 0.089 & 0.083 & 0.089 & 0.863 & 0.101 & 0.081 & 0.037 & \\
\hline
\end{tabular}

Phylogenetic tree of javan hawk-eagle. According to the neighbor-joining tree reconstruction, we confirmed that the five samples, FM01, FW01, RR04, RR21, and RR24 belonged to the same species since they formed a single clade with a bootstrap value of 97 . The tree also confirmed that the reference sequence, $S$. alboniger AP008239.1 and N. bartelsi were sister species, with a bootstrap value of 88 . They formed a monophyletic branch along with $N$. nipalensis, with a bootstrap value of 97 . This monophyletic group split from the other Spizaetus groups, consisting of $S$. tyrannus, $S$. melanoleucus, $N$. cirrhatus, and S. philippensis (Figure 2).

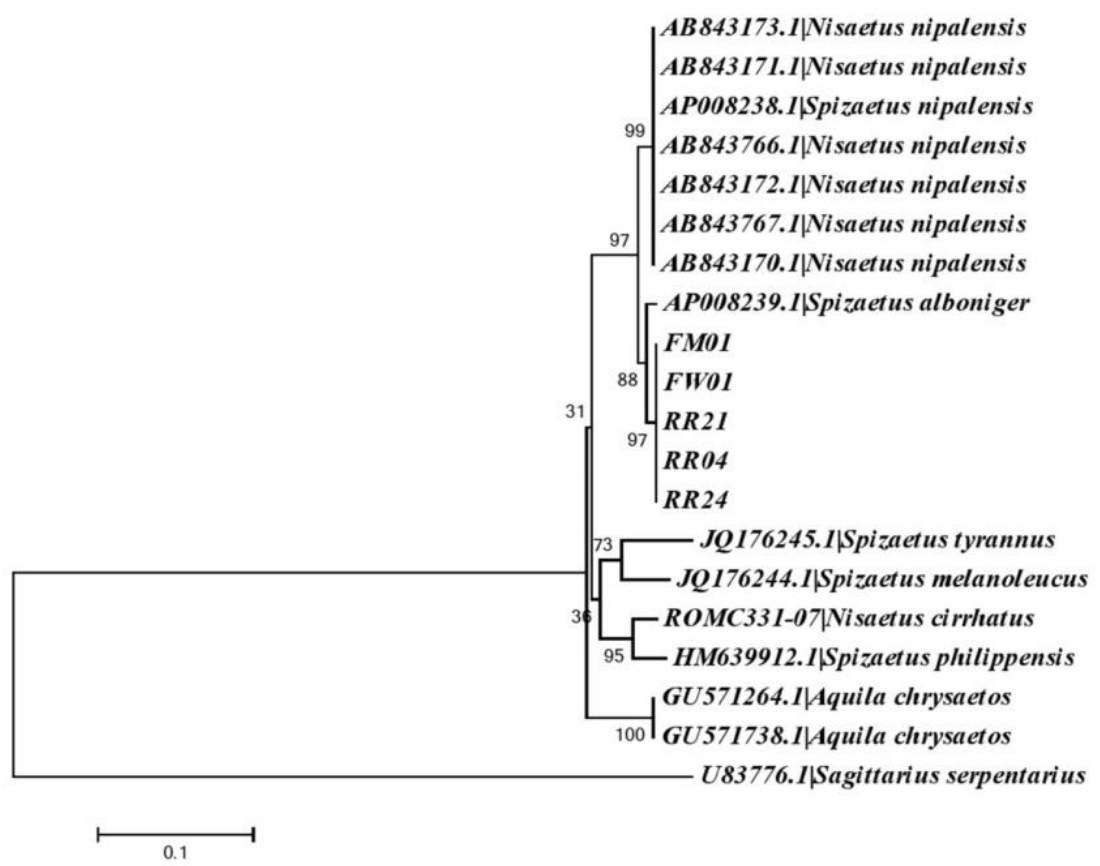

Figure 2. Phylogenetic tree of Javan hawk-eagle and the other species in Accipitridae family. 
The Javan hawk-eagle used to be grouped in the genus Spizaetus, which distributes in South America, due to their shared morphological characteristics, including long tails and feathered tarsi. The latest studies at the molecular level suggest that all hawk-eagle species in Asia separated earlier from genus Spizaetus and formed a monophyletic branch named Nisaetus (Gamauf et al., 2005; Helbig et al., 2005; Lerner et al., 2017). However, the new phylogeny and taxonomy did not necessarily change the registered sequence names in the Genebank of the NCBI database. This explains why several reference sequences in this study still bear the genus name Spizaetus.

Genus Nisaetus comprises all species of hawk-eagles distributed in Asia, including Southeast Asia, with some species endemic to particular areas (Lerner et al., 2017). The geographical condition of southeast Asia is the major factor for its high rate of species endemicity, with the Javan hawk-eagle as an example (Gamauf et al., 2005). The Javan hawkeagle particularly inhabits the primary rainforests of Java and shares the habitat generically with the changeable hawk-eagle (N. chirrhatus) (Nijman, 2004). The two species prefer similar prey. Thus, they also share the same ecological role as toporder predators. Despite the similarities in their ecological roles on the island of Java, according to this study, the two species are not closely related; in fact, the two species sit on different clades.

On the other hand, according to this study, the Javan hawk-eagle was at the same clade with the Blyth's hawk-eagle ( $N$. alboniger or S. alboniger AP008239.1), which is distributed in the closed forests of Sumatra and Borneo, as sister species. Morphologically, the Javan hawk-eagle shares many characteristics with the Blyth's hawk-eagle (N. alboniger), such as the feathered tarsi, plumage pattern and distinct crest, other than their color. $N$. bartelsi has cinnamon brown plumage that grows darker, barred breast and stripes that grow clearer as the bird ages. Meanwhile, its sister species, the Blyth's hawk-eagle (N. alboniger), has black and white plumage with a spotted breast and barred underparts (IUCN, 2016). This is because of the Javan hawk-eagle (N. bartelsi) along with the Blyth's hawk-eagle ( $N$. alboniger) came from different lineages of the changeable hawk-eagle (N. cirrhatus) (Gjershaug, 2006).
The changeable hawk-eagle (N. cirrbatus) has a much wider distribution, ranging throughout southeast Asia, specializing in forest edges and open woodlands (Ferguson \& Christie, 2001). In Java, it can also be found in primary rainforests, along with the Javan hawk-eagle (Nijiman, 2004). However, the interspecific genetic distance data reveals that the two species are not closely related, despite their similar habitat preferences and hunting behaviors. The high interspecific genetic distance between $N$. bartelsi and $N$. cirrbatus $(0.081)$ indicates that the two groups had already split even before the South American and African hawk-eagle lineages separated (Lerner \& Mindell, 2005; Haring et al., 2007); a close interspecific genetic distance of 0.013 with $N$. alboniger shows that the Javan hawk-eagle ( $N$. bartelsi) split from their ancestral population due to the rising sea level, which separated Java from Sumatra and Borneo and isolated the Javan hawk-eagle population (Gamauf et al., 2005; Haring et al., 2007; Lerner et al., 2017).

Moreover, the Javan hawk-eagles and the changeable hawk-eagles in Java are segregated by habitat, by the topography of the terrains, and partially by altitude. N. bartelsi occurs over a smaller range of habitats than $N$. cirrbatus. The once dense continuous rainforest of Java has been fragmented into numerous small patches or has been replaced by more open habitat types, to which Javan hawk-eagles are not well adapted (Nijman, 2004). This condition enhances the significant genetic divergence with the changeable hawk-eagle and generates this species' endemicity as it prevents gene flow from one population of Javan hawk-eagles to the others (Gamauf et al., 2005).

A reliable diagnosis of the taxonomic status of populations is essential for conservation because unrecognized species may become extinct due to a lack of information, including genetic information, which can lead to a lack of protection (Gamauf et al., 2005). A taxonomic unit as detailed as the species level is usually prioritized in conservation measures as an evolutionarily significant unit (Frankham, 2002). As a result, the phylogenetic species concept affects conservation more than any other disciplines (Collar, 1997). 


\section{CONCLUSION}

The COI gene sequences obtained from the five samples with the code names FM01, FW01, RR04, RR21, and RR24 had 744, 742, 734, 724, and 741 base pairs, respectively.

According to the phylogenetic analysis, Javan hawk-eagles FM01, FW01, RR04, RR21, and RR224 was confirmed as one species, N. bartelsi, a sister species of Nisaetus (Spizaetus) alboniger AP008239.1. Thus, the DNA barcoding of the Javan hawk-eagle conducted in this study is a stepping stone to conservation efforts for the Javan hawk-eagle.

\section{REFERENCES}

BirdLife International. 2016. Nisaetus bartelsi. United Kingdom: The IUCN Red List of Threatened Species.

Collar, N. 1997. Taxonomy and conservation: chicken and egg. Bull British Ornithologists' Club 117: 122-136.

Collar, N. J., Andreev, J. V., Chan, S., Crosby, M. J., Subramanya, S., \& Tobias, J. A. 2001. Threatened birds of Asia: the birdlife international red data book. Cambridge: BirdLife International.

Ferguson-Lees J. \& Christie, D.A. 2001. Raptors of the world. London: Christopher Helm.

Frankham, R., Ballou, D. J., \& Briscoe, D. A. 2002. Conservation genetics. Cambridge: Cambridge University Press.

Frankham, R. 2003. Genetics and conservation biology. Comptes Rendus Biology 326: 22-29.

Gamauf, A., Gjershaug, J. O., Nils, R., Kvaløy, K., \& Haring, E. 2005. Species or subspecies? the dilemma of taxonomic ranking of some South-East Asian hawk-eagles (Genus Spizaetus). Bird Conservation International 15: 99-117.

Gjershaug, J. O., Rov, N., Nygard, T., Prawiradilaga, D. M., Afianto, M. Y., Hapsoro \& Supriatna, A. 2004. Home-range size of the Javan Hawk-eagle (Spizaetus bartelsi) estimated from direct observations and radiotelemetry. Journal of Raptor Research 38: 343-349.

Gjershaug, J. O. 2006. Taxonomy and conservation status of hawk-eagles (genus Nisaetus) in South-East Asia [dissertation]. Trondheim, Norway: Norwegian University of Science and Technology.

Hajibabaei, M., Singer, G. A. C., Hebert, P. D. N., \& Hickey, D. A. 2007. DNA Barcoding how it complements taxonomy, molecular phylogenetics, and population genetics. Trends Genetics 23: 167-172.

Haring, E., Kvaløy, K., Gjershaug, J.O., Røv, N. \& Gamauf, A. 2007. Convergent evolution and Paraphyly of the Hawkeagles of the Genus Spizaetus (Aves, Accipitridae) Phylogenetic Analyses Based on Mitochondrial Markers. Journal of Zoological Systematics and Evolutionary Research 45: 353-365.

Hebert, P. D. N., Cywinska, A., Ball, S. L., \& de Waard, J. R. 2003. Biological identifications through DNA barcodes. Proceedings of the Royal Society of London B 270: 313-321.

Hebert, P. D. N., Stoeckle, M. Y., Zemlak, T. S., \& Francis, C. M. 2004. Identification of birds through DNA barcodes. PLoS
Biology 2: e312.

Helbig, A. J., Kocum, A., Seibold, I., \& Braun, M. J. 2005. A multigene phylogeny of aquiline eagles (Aves: Accipitriformes) reveals extensive paraphyly at the genus level. Molecular Phylogenetics and Evolution 35: 147-164.

IUCN (World Conservation Union). 1980. World conservation strategy: living resource conservation for sustainable development. Gland, Switzerland: IUCN/United Nations Environment Program/World Wildlife Fund.

IUCN. 2016. The IUCN red list of threatened species version 2016-3; [accessed 2016 Dec 07]. www.iucnredlist.org.

Keller, L. F. \& Waller, D. M. 2002. Inbreeding effects in wild populations. Trends Ecology Evolution 17: 230-241.

Kress, W. J., Garcia-Robledo, C., Uriarte, M., \& Erickson, D. L. 2015. DNA barcodes for ecology, evolution, and conservation. Trends Ecology Evolution 30: 25-35.

Lerner, H., Christidis, L., Gamauf, A., Griffiths, C., Haring, E., Huddleston, C. J., Kabra, S., Kocum, A., Krosby, M., \& Kvaløy K. 2017. Phylogeny and new taxonomy of the Booted Eagles (Accipitriformes: Aquilinae). Zootaxa 4216: 301-320.

Lerner, H. \& Mindell, D. P. 2005. Phylogeny of eagles, Old World vultures, and other Accipitridae based on nuclear and mitochondrial DNA. Molecular Phylogenetics and Evolution 37: 327-346. 21

Nei, M. \& Saitou, N. 1987. The Neighbor-joining Method: A New Method for Reconstructing Phylogenetic Trees. Molecular Biology and Evolution 44:406-425.

Nijman, V., Shepherd, C. R., \& Van Balen, S. 2009 Declaration of the Javan hawk eagle Spizaetus bartelsi as Indonesia's National Rare Animal impedes conservation of the species. Oryx 43: 122-128.

Nijman, V. \& Sözer, R. 1998. Field identification of the javan hawk eagle Spizaetus bartelsi. Forktail 14: 13-16.

Nijman, V. 2004. Habitat segregation in two congeneric hawkeagles (Spizaetus bartelsi and S. cirrhatus) in Java, Indonesia. Journal of Tropical Ecology 20: 105-111.

Prawiradilaga, D. M. 2006. Ecology and conservation of endangered Javan hawk-eagle Spizaetus bartelsi. Ornithological Science 5 177-186.

Sozer, R., Nijman, V., Setiawan, I., Van Balen, S., Prawiradilaga, D. M., \& Subijanto. 1998. Javan Hawk-Eagle Recovery Plan. Bogor: KMNLH/PHPA/LIPI/BirdLife International Indonesia Programme.

Syartinilia \& Tsuyuki, S. 2008. GIS-based modeling of Javan Hawk-eagle distribution using logistic and autologistic regression models. Biological Conservation 141: 756769.

Van Balen, S., Nijman, V., \& Prins, H. H. T. 2000. The Javan hawkeagle: misconceptions about rareness and threat. Biological Conservation 96: 297-304.

Van Balen, S., Nijman, V., \& Sözer R. 2001. Conservation of the endemic Javan Hawk-eagle Spizaetus bartelsi Stresemann, 1924 (Aves: Falconiformes): density, age structure, and population numbers. Contributions to Zoology 70: 161-173.

Widyastuti, Y. E. 1993. Flora-fauna maskot nasional dan propinsi. Jakarta: Penebar Swadaya.

Winter, M., Devictor, V., \& Schweiger, O. 2012. Phylogenetic diversity and nature conservation: where are we?. Trends Ecology Evolution 28: 199-204.

Zein, M. S. A \& Prawiradilaga, D. M. 2013. DNA Barcode Fauna Indonesia. Jakarta: Kencana

Tamura, K., Stecher, I., Peterson, D., Filipski, A., \& Kumar, S. 2013. MEGA6: Molecular Evolutionary Genetics Analysis Version 6.0. Molecular Biology and Evolution 30(12): 27252729. 